\title{
Melting temperature of Ti and TiAl nanoparticles in vacuum and in Al matrix depending on their diameter: molecular dynamics study
}

\author{
G. M. Poletaev ${ }^{\dagger}$, A. A. Sitnikov, V. Yu. Filimonov \\ †gmpoletaev@mail.ru
}

Altai State Technical University, Barnaul, 656038, Russia

\begin{abstract}
The dependence of the melting temperature of $\mathrm{Ti}$ and $\mathrm{TiAl}$ nanoparticles on their diameter in vacuum and in $\mathrm{Al}$ matrix was studied by the method of molecular dynamics using EAM potentials of Zope and Mishin. Particles with a diameter of 2.5 to $12 \mathrm{~nm}$ were considered. The obtained values of the melting point are in good agreement with the approximation curves constructed on the basis that the decrease in the melting temperature is proportional to the ratio of the surface area of the particle to its volume. Wherein the values of the melting temperature of Ti and TiAl particles in the aluminum matrix turned out to be lower than those of particles in vacuum, which is explained by the smearing and disordering of the interface due to mutual diffusion. As the size of particles in vacuum and in aluminum increased, the values of their melting points tended to the same value, which is explained by the decrease in the role of the diffusion-blurred interface with an increase in the particle diameter. The particles began to melt from the surface. The velocity of movement of the melting front depended on temperature and increased with increasing temperature. In the case of particles in aluminum matrix, at temperatures close to the particle melting point, mutual diffusion was significantly accelerated due to melting of the particle boundary layer. $\mathrm{Al}$ atoms penetrating into the particle accelerated the movement of the melting front, rapidly occupying the next destroyed layer of the particle.
\end{abstract}

Keywords: molecular dynamics, nanoparticle, melting temperature, titanium, titanium aluminide.

УДК: 538.971

\section{Температура плавления наночастиц Ti и TiAl в вакууме и в матрице Al в зависимости от их диаметра: молекулярно-динамическое исследование \\ Полетаев Г. М. ${ }^{\dagger}$ Ситников А. А., Филимонов В. Ю. \\ Алтайский государственный технический университет им. И. И. Ползунова, Барнаул, 656038, Россия}

\begin{abstract}
Методом молекулярной динамики проведено исследование зависимости температуры плавления наночастиц Ті и TiAl от их диаметра в вакууме и в алюминиевой матрице с использованием ЕАМ потенциалов Зоупа и Мишина. Рассматривались частицы диаметром от 2.5 до 12 нм. Полученные значения температуры плавления хорошо совпали с аппроксимационными кривыми, построенными из соображения, что снижение температуры плавления пропорционально отношению площади поверхности частицы к ее объему. При этом значения температуры плавления частиц Ti и $\mathrm{TiAl}$ в алюминиевой матрице оказались ниже, чем частиц в вакууме, что объясняется размытием и разупорядочением границы раздела вследствие взаимной диффузии. По мере увеличения размера частиц в вакууме и алюминии значения их температуры плавления стремились к одной и той же величине, что объясняется снижением роли размытой из-за диффузии границы раздела с ростом диаметра частицы. Плавление частиц начиналось с поверхности. Скорость движения фронта плавления зависела от температуры и возрастала с повышением температуры. В случае частиц в матрице алюминия, при температурах близких к температуре плавления частицы, взаимная диффузия существенно ускорялась из-за плавления приграничного слоя частицы. Проникающие в частицу атомы $\mathrm{Al}$ ускоряли движение фронта плавления, быстро занимая очередной разрушенный слой частицы.
\end{abstract}

Ключевые слова: молекулярная динамика, наночастица, температура плавления, титан, алюминид титана. 


\section{Introduction}

Titanium aluminide TiAl is an important intermetallic compound that has considerable development potential as a high-temperature structural material for the aerospace and automobile industries [1-4]. Its advantageous features are low density, high melting temperature, excellent oxidation and corrosion resistance. A promising direction for obtaining new composite materials is the creation of intermetallic alloys of the $\mathrm{Ti}-\mathrm{Al}$ system in a nanostructured state. One of the technological methods for the formation of such a state is mechanoactivation treatment, which makes it possible to achieve the limiting degree of grain refinement [5-7]. In the process of mechanical activation, the so-called mechanocomposites are formed, which are, as a rule, a matrix of a more plastic component, in the volume of which there are small particles, including nanosized, of a more fragile component of the mixture [6,7]. Such a system is characterized by a high degree of non-equilibrium due to a high concentration of defects, interfaces and internal stresses.

It is known that the melting point of nanosized particles decreases due to the high fraction of the surface in relation to their volume [8-13]. A decrease in the melting temperature of metal nanoparticles with a decrease in their diameter has been well studied and has been repeatedly confirmed experimentally, for example [9-11]. Strictly speaking, a true phase transition, of course, should be considered a transition in an infinitely large thermodynamic system, as suggested in [8], but, nevertheless, a decrease in the melting point of nanoparticles is a real fact that should be taken into account in models and technological operations.

In the mechanocomposites of the $\mathrm{Ti}-\mathrm{Al}$ system, small $\mathrm{Ti}$ particles and intermetallic nuclei are located in the aluminum matrix, which obviously changes the relationship between the particle size and their melting point as compared to the presence of the corresponding particles in vacuum. Moreover, the influence of the matrix can be ambiguous. On the one hand, the presence of aluminum can reduce the average energy of the atoms of the particle near the interface, i.e. reduce the effect of the surface on the melting point. But, on the other hand, at temperatures close to the melting temperature, mutual diffusion proceeds intensively, as a result of which the boundary is blurred, and the number of conventional "boundary" atoms becomes larger. This work is devoted to a molecular dynamics study of the dependence of the melting temperature of Ti and TiAl nanoparticles on their diameter in vacuum and in aluminum matrix using EAM potentials.

\section{Description of the model}

The study was carried out using the own program for molecular dynamics calculations MDR [14]. EAM potentials constructed by Zope and Mishin [15] were used to describe interatomic interactions in the Ti-Al system. These potentials, which were obtained by fitting to both experimental and firstprinciples data of various crystal properties and structures in $\mathrm{Ti}-\mathrm{Al}$ system, give a good description of basic properties such as lattice parameters, elastic constants, point and planar defects energies, thermal expansion [15-17].

To simulate a particle in a vacuum and a matrix of another metal, a model similar to the models in $[13,18]$ was used. The particle was created in the model by cutting out a ball of the corresponding size from an ideal crystal. An example of a TiAl particle with a diameter of $7 \mathrm{~nm}$ is shown in Fig. 1a. To simulate the aluminum matrix, a shell was created around the particle, containing about the same number of atoms as the particle (Fig. 1b).

Particles with a diameter of 2.5 to $12 \mathrm{~nm}$ were considered. After cutting out a particle from the crystal, structural relaxation was carried out at a starting temperature of $0 \mathrm{~K}$, at the end of which the particle was cooled. The particle was in a computational cell in the form of a rectangular parallelepiped. For this model, both free and periodic boundary conditions can be used. We used periodic ones, because in this case the atoms evaporating from the surface always remained inside the computational cell. The distance between the walls of the cell was large enough to exclude the interaction of the particle with its virtual twin.

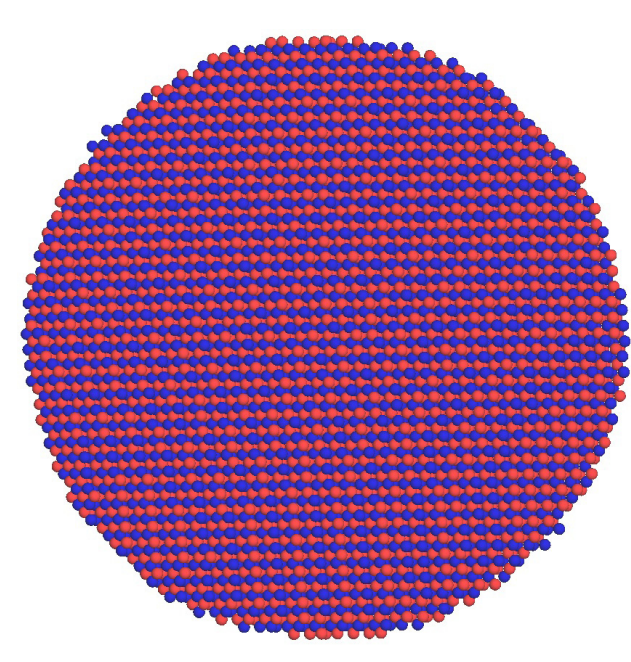

a

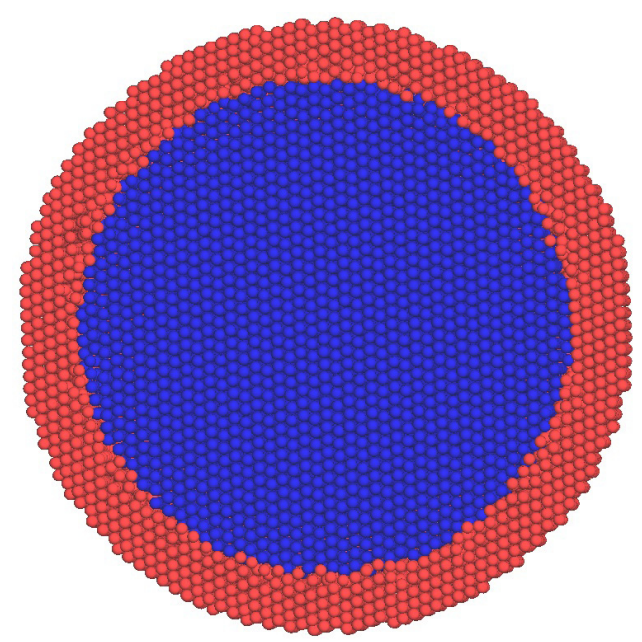

$\mathrm{b}$

Fig. 1. (Color online) Examples of starting nanoparticles: TiAl with a diameter of $7 \mathrm{~nm}(\mathrm{a})$; Ti particle with a diameter of $10 \mathrm{~nm}$ in $\mathrm{Al}$ shell (section) (b). $\mathrm{Ti}$ - blue atoms, $\mathrm{Al}$ - red atoms. 
The temperature in the model was set through the initial velocities of the atoms according to the Maxwell-Boltzmann distribution, wherein the thermal expansion of the calculation blocks was taken into account [19-22]. Due to the fact that at high temperatures diffusion at the Ti-Al interface proceeds actively and the boundary is rapidly blurred, the method of searching for the melting temperature by gradually increasing the temperature, as in $[12,13]$, was excluded. In our work, we began each experiment with a starting structure, setting one or another temperature, keeping it constant using a NoseHoover thermostat. One experiment lasted from 20 to 500 ps, depending on particle size and melting front velocity. The time integration step in the molecular dynamics method was $2 \mathrm{fs}$. The melting point of the particles was determined from a relatively sharp increase in the average potential energy of $\mathrm{Ti}$ atoms (Fig. 2). In addition, melting, as will be shown in the figures below, was often clearly visible visually. For a rough estimate of the melting point, the temperature was first changed with a step of $100 \mathrm{~K}$. Then, for a more accurate determination, near the melting point, the step was decreased down to $5 \mathrm{~K}$.

\section{Results and discussion}

Fig. 3 shows the obtained dependences of the melting temperatures of particles on their diameter in vacuum and in aluminum matrix. The figures also show the corresponding approximation curves obtained with the assumption that the decrease in the melting temperature is proportional to the ratio of the surface area of the particle to its volume:

$$
T_{m}(d)=T_{m}^{0}-\frac{a}{d-\delta} .
$$

Here $T_{m}$ and $T_{m}^{0}$ are the melting temperatures of the particle and the bulk material, $d$ is the particle diameter, $a$ and $\delta$ are parameters, wherein $\delta$ in a sense characterizes the thickness or smearing of the particless surface layer.

The obtained values are in good agreement with the approximation curves, which confirms this thesis and the well-known fact about a decrease in the melting temperature of nanoparticles as their diameter decreases [8-13]. For particles in aluminum matrix, in this case, it was necessary

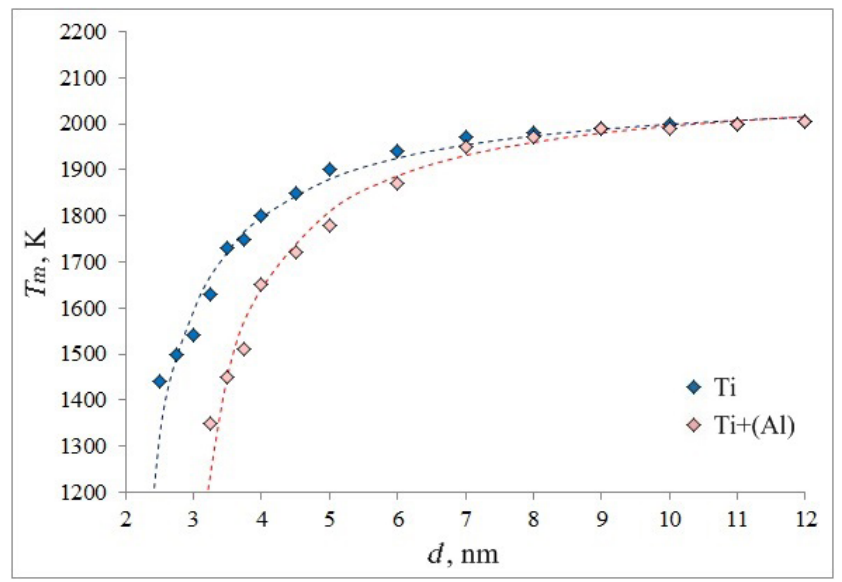

a

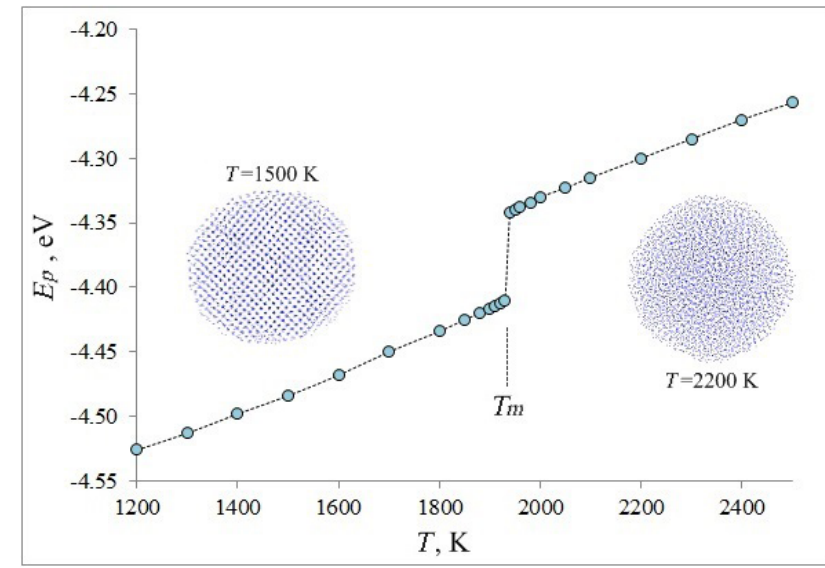

Fig. 2. Change with increasing temperature of the average potential energy of Ti atoms in a particle with a diameter of $6 \mathrm{~nm}$.

to make a correction (to increase the parameter $\delta$ ), as if the real diameter of the particle was less than the specified one, which was obviously caused by the blurring of the boundary due to diffusion. A decrease in the melting point of particles initially of the same size in aluminum matrix was observed for both Ti (Fig. 3 a) and TiAl (Fig. 3 b) particles. At the same time, as the particle size increased, the values of their melting temperatures tended to the same value, which is explained by the decrease in the role of the diffusion-blurred interface with an increase in the particle diameter.

The obtained data are also additional approbation of Zope-Mishin EAM potentials. The melting point of titanium ( $1995 \mathrm{~K}$ in the model) coincided well with the reference value (1943 K). However, for the TiAl intermetallic, a value of $2330 \mathrm{~K}$ was obtained, which is $35 \%$ higher than the reference value $(1720 \mathrm{~K}[1])$. Obviously, this is a weak point of the Zope and Mishin potentials; nevertheless, as was shown in [15-17], these potentials describe quite well simultaneously a wide range of other characteristics of the intermetallic compound, which makes them one of the best for describing the Ti-Al system in molecular dynamics models.

The particles began to melt from the surface. The movement of the melting front was clearly visible visually in the model, especially in the case of relatively large particles. Fig. 4 a shows Ti particle with a diameter of $10 \mathrm{~nm}$ during

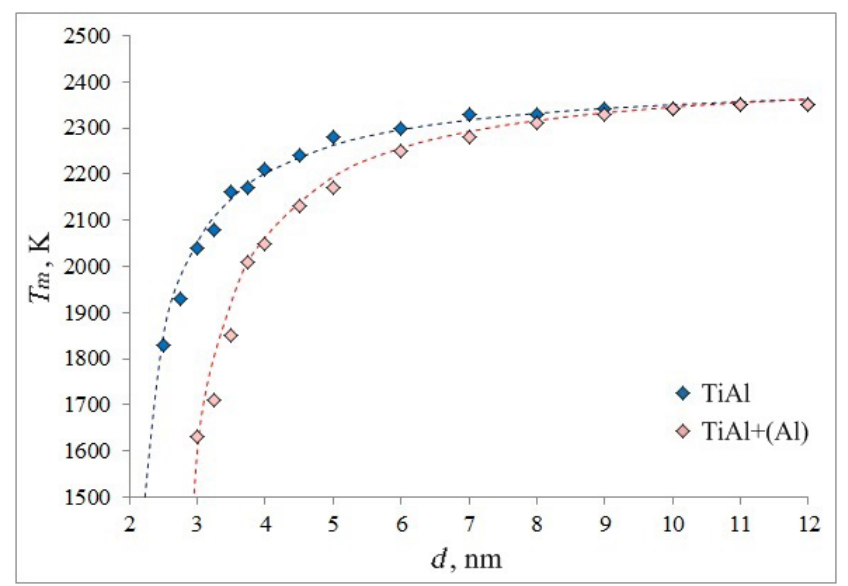

b

Fig. 3. (Color online) Dependences of the melting temperature on the particle diameter in vacuum (blue) and in aluminum matrix (red): $\mathrm{Ti}(\mathrm{a}), \mathrm{TiAl}(\mathrm{b})$. 


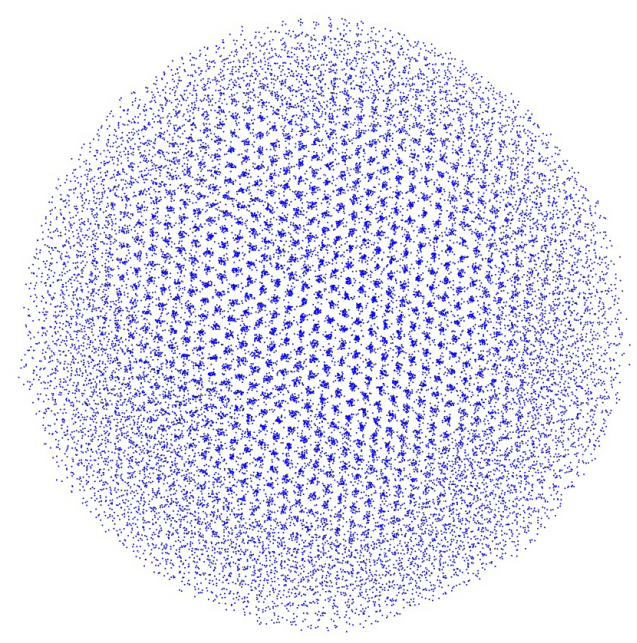

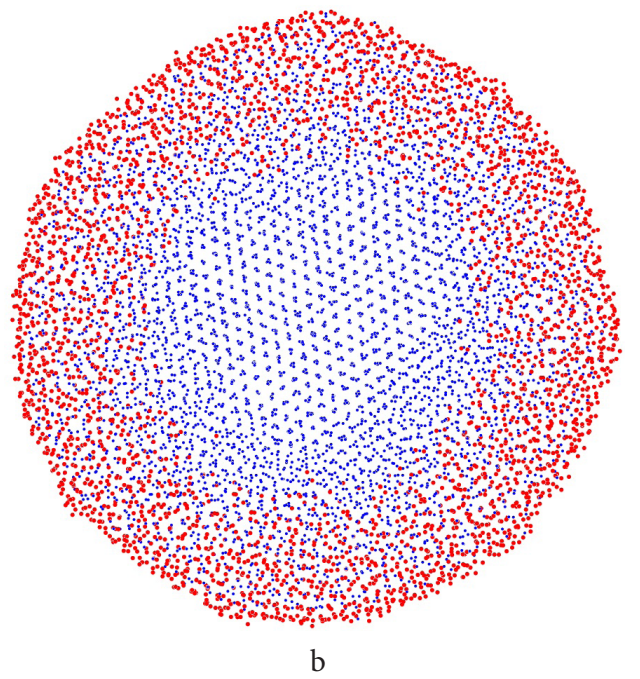

Fig. 4. (Color online) The structure of the central layer of a particle during melting: melting front moving from a free surface in Ti particle with a diameter of $10 \mathrm{~nm}$ at a temperature of $2000 \mathrm{~K}$ at a time of $150 \mathrm{ps}$ (a); blurred, as a result of diffusion, boundary between Ti and Al, Ti particle with a diameter of $9 \mathrm{~nm}$ in $\mathrm{Al}$ shell at a temperature of $1970 \mathrm{~K}$ at a time of $45 \mathrm{ps}$ (b).

melting, which is specially rotated so that the atomic rows of the crystal core are clearly visible. The velocity of the front movement depended on temperature and increased with increasing temperature. According to $[23,24]$, the meltingcrystallization front in metals moves at a velocity of the order of several tens of $\mathrm{m} / \mathrm{s}$, decreasing almost to zero at the melting temperature. The front velocity was not constant and increased as the size of the crystal core decreased. Near the melting point, two-phasity (the simultaneous presence of a solid core and a liquid shell) in the case of relatively large particles could be observed for a relatively long time in the model. Nevertheless, eventually, it disappears and ends either with the complete melting of the particle or its crystallization.

In the case of the presence of aluminum shell around the particle, at temperatures above the melting point of aluminum (about $900 \mathrm{~K}$ in the model), intense mutual diffusion began at the $\mathrm{Ti}-\mathrm{Al}$ or TiAl-Al interface, the rate of which, however, in most cases was lower than the velocity of the melting front (Fig. 4b). The expanding diffusion zone loosened up the boundary to a large extent, disrupting its crystal structure. At temperatures close to the melting point of the particle, diffusion intensified even more due to the melting of the boundary layer of the particle. $\mathrm{Al}$ atoms penetrating into the particle accelerated the movement of the melting front, rapidly occupying the next destroyed layer of the particle.

In the $\mathrm{TiAl}+(\mathrm{Al})$ system at the same temperatures, diffusion proceeded weaker than in the $\mathrm{Ti}+(\mathrm{Al})$ system, which is explained by the comparatively stronger interatomic bonds in the intermetallic compound. However, near the melting point of TiAl, a similar situation arose as in the case of the $\mathrm{Ti}+(\mathrm{Al})$ system - the resulting liquid-liquid-phase contact at the interface led to intense diffusion and practically the same effect of decreasing the melting point as in the case of a Ti particle.

\section{Conclusion}

The dependence of the melting temperature of $\mathrm{Ti}$ and TiAl nanoparticles on their diameter in vacuum and in $\mathrm{Al}$ matrix was studied by the method of molecular dynamics using EAM potentials of Zope and Mishin. The obtained values of the melting point are in good agreement with the approximation curves constructed on the basis that the decrease in the melting temperature is proportional to the ratio of the surface area of the particle to its volume. Wherein the values of the melting temperature of $\mathrm{Ti}$ and TiAl particles in the aluminum matrix turned out to be lower than those of particles in vacuum, which is explained by the smearing and disordering of the interface due to mutual diffusion. As the size of particles in vacuum and in aluminum increased, the values of their melting points tended to the same value, which is explained by the decrease in the role of the diffusion-blurred interface with an increase in the particle diameter.

The particles began to melt from the surface. The velocity of movement of the melting front depended on temperature and increased with increasing temperature. In the case of particles in aluminum matrix, at temperatures close to the particle melting point, mutual diffusion was significantly accelerated due to melting of the particle boundary layer. Al atoms penetrating into the particle accelerated the movement of the melting front, rapidly occupying the next destroyed layer of the particle.

Acknowledgements. The study was supported by Ministry of Science and Higher Education of the Russian Federation (FZMM-2020-0002).

\section{References}

1. S.G. Grigorenko, G.M. Grigorenko, O.M. Zadorozhnuk. Modern electrometallurgy. 128 (3), 51 (2017). (in Russian) [С. Г. Григоренко, Г.М. Григоренко, О.М. Задорожнюк. Современная электрометаллургия. 128 (3), 51 (2017).] Crossref

2. J. Lapin. Proceedings of the Metal. 19 (21.5), 2019 (2009).

3. T. Tetsui. Rare Metals. 30, 294 (2011). Crossref

4. T. Voisin, J.-P. Monchoux, A. Couret. In: Spark Plasma Sintering of Materials (Ed. by P. Cavaliere). Springer, Switzerland (2019) pp. $713-737$. 
5. V. V. Boldyrev, K. Tkacova. Journal of Materials Synthesis and Processing. 8 (3), 121 (2000). Crossref

6. V.Y. Filimonov, M.A. Korchagin, N.Z. Lyakhov, I. A. Dietenberg, A. N. Tyumentsev. Powder Technology. 235, 606 (2013). Crossref

7. M.V. Loginova, V.I. Yakovlev, V.Yu. Filimonov, A.A. Sitnikov, A.V. Sobachkin, S.G. Ivanov, A. V. Gradoboev. Letters on Materials. 8 (2), 129 (2018). (in Russian) [М. В. Логинова, В.И. Яковлев, В.Ю. Филимонов, А.А. Ситников, А.В. Собачкин, С. Г. Иванов, А. В. Градобоев. Письма о материалах. 8 (2), 129 (2018).] Crossref

8. E. L. Nagaev. Soviet Physics Uspekhi. 35 (9), 747 (1992). Crossref

9. Ph. Buffat, J.-P. Borel. Phys. Rev. A. 13, 2287 (1976). Crossref

10. G. L. Allen, R. A. Bayles, W.W. Gile, W.A. Jesser. Thin Solid Films. 144 (2), 297 (1986). Crossref

11. T. Castro, R. Reifenberger, E. Choi, R. P. Andres. Phys. Rev. B. 42, 8548 (1990). Crossref

12. V.M. Samsonov, S.S. Kharechkin, S.L. Gafner, L. V. Redel>, Yu. Ya. Gafner. Crystallography Reports. 54 (3), 526 (2009). Crossref

13. I. V. Chepkasov, Y.Y. Gafner, L. V. Redel', M. A. Vysotin. Physics of the Solid State. 59 (10), 2076 (2017). Crossref

14. G. M. Poletaev. Molecular dynamics research (MDR). Certificate of state registration of a computer program
No. 2015661912, 12.11.2015. (in Russian) [Г. М. Полетаев. Molecular dynamics research (MDR). Свидетельство о государственной регистрации программы для ЭВМ № 2015661912 от 12.11.2015.]

15. R. R. Zope, Y. Mishin. Phys. Rev. B. 68, 024102 (2003). $\underline{\text { Crossref }}$

16. Y.-K. Kim, H.-K. Kim, W.-S. Jung, B.-J. Lee. Computational Materials Science. 119, 1 (2016). Crossref

17. Q.-X. Pei, M.H. Jhon, S.S. Quek, Z.Wu. Computational Materials Science. 188, 110239 (2021). Crossref

18. E. V. Levchenko, A. V. Evteev, T. Lorscheider, I. V. Belova, G.E. Murch. Computational Materials Science. 79, 316 (2013). Crossref

19. G. M. Poletaev, I. V. Zorya. Journal of Experimental and Theoretical Physics. 131 (3), 432 (2020). Crossref

20. G. M. Poletaev, I.V. Zorya, R.Y. Rakitin, M.A. Iliina. Materials Physics and Mechanics. 42 (4), 380 (2019). Crossref

21. R.Yu. Rakitin, G.M. Poletaev, M.S. Aksenov, M. D. Starostenkov. Technical Physics Letters. 31 (8), 650 (2005). Crossref

22. G. M. Poletaev, M.D. Starostenkov. Technical Physics Letters. 29 (6), 454 (2003). Crossref

23. W.-L. Chan, R.S. Averback, D. G. Cahill, Y. Ashkenazy. Physical Review Letters. 102, 095701 (2009). Crossref

24. M.I. Mendelev, F. Zhang, H. Song, Y. Sun, C.Z. Wang, K. M. Ho. The Journal of Chemical Physics. 148, 214705 (2018). Crossref 